\title{
Transient Elevations of Cytosolic Free Calcium Retard Subsequent Apoptosis in Neutrophils In Vitro
}

\author{
Moira K. B. Whyte, ${ }^{\star}$ Simon J. Hardwick, ${ }^{\star}$ Laura C. Meagher, ${ }^{\star}$ John S. Savill, ${ }^{\star}$ and Christopher Haslett ${ }^{5}$ \\ Departments of ${ }^{*}$ Medicine (Respiratory Division) and ${ }^{\ddagger}$ Clinical Pharmacology, Royal Postgraduate Medical School, Hammersmith \\ Hospital, London W12 ONN; and ${ }^{\S}$ Department of Respiratory Medicine, City Hospital, Edinburgh EH10 5SB, United Kingdom
}

\begin{abstract}
Elevation of cytosolic calcium $\left(\left[\mathrm{Ca}^{2+}\right]_{i}\right)$ has been reported to induce apoptosis in a number of cell types. However, in the neutrophil, which undergoes apoptosis constitutively during aging in vitro, activation by inflammatory mediators elevates $\left[\mathrm{Ca}^{2+}\right]_{i}$ and prolongs lifespan via inhibition of apoptosis. To examine this paradox, we investigated the effects of modulation of $\left[\mathrm{Ca}^{2+}\right]_{i}$ upon apoptosis of neutrophils in vitro. Calcium ionophores (A23187, ionomycin) retarded apoptosis in neutrophil populations after 20 h $(P<0.001)$. Conversely, intracellular $\mathrm{Ca}^{2+}$-chelation, using bis-(o-aminophenoxy)- $N, N, N, N^{\prime}$-tetraacetic acid (BAPTA) acetoxymethyl ester (AM) promoted apoptosis $(P<0.02)$. W-7 (an inhibitor of calmodulin) also promoted apoptosis $(P<0.05)$. Measurements of $\left[\mathrm{Ca}^{2+}\right]_{i}$, using fura-2, showed $(a)$ increased apoptosis in neutrophil populations was not associated with elevated $\left[\mathrm{Ca}^{2+}\right]_{i},(b)$ neutrophils cultured with ionophore at concentrations inhibiting apoptosis exhibited transient $\left(<1 \mathrm{~h}\right.$ ) elevations of $\left[\mathrm{Ca}^{2+}\right]_{i}$, to levels previously reported with receptor-mediated stimuli, and (c) BAPTA was able to prevent the elevation of $\left[\mathrm{Ca}^{2+}\right]_{i}$ and the inhibition of apoptosis produced by ionophore. Modulation of apoptosis occurred without alterations in intracellular $\mathrm{pH}$. Thus, in the neutrophil, unlike lymphoid cells, elevation of $\left[\mathrm{Ca}^{2+}\right]_{i}$ exerts an inhibitory effect upon apoptosis. Furthermore, these data suggest that transient elevation of $\left[\mathrm{Ca}^{2+}\right]_{i}$ elicits signaling events leading to prolonged inhibition of apoptosis. (J. Clin. Invest. 1993. 92:446-455.) Key words: programmed cell death • granulocyte • calcium ionophore $\bullet$ calcium chelation • calmodulin
\end{abstract}

\section{Introduction}

Apoptosis is a highly organized mechanism by which cells undergo programmed cell death. In a wide range of cell types, common morphological and molecular events bring about this "physiological" death $(1,2)$. The morphological events characterizing apoptosis are cytoplasmic and nuclear condensation (3) and the biochemical "hallmark" is internucleosomal chromatin fragmentation (4). There has been intense interest in the intracellular events mediating programmed cell death. In particular, previous studies in lymphoid cells have implicated in-

Address correspondence to Dr. Moira Whyte, Respiratory Division, Department of Medicine, Royal Postgraduate Medical School, Hammersmith Hospital, London W12 ONN, United Kingdom.

Received for publication 22 June 1992 and in revised form 5 January 1993.

J. Clin. Invest.

(C) The American Society for Clinical Investigation, Inc.

$0021-9738 / 93 / 07 / 0446 / 10 \$ 2.00$

Volume 92, July 1993, 446-455 creases in intracellular free calcium $\left(\left[\mathrm{Ca}^{2+}\right]_{\mathrm{i}}\right)^{1}$ in the triggering of apoptosis. For example, elevation of $\left[\mathrm{Ca}^{2+}\right]_{i}$, either directly via calcium ionophore $(5)$ or indirectly with "physiological" stimuli, such as corticosteroids (6) or anti-CD3 receptor antibodies (7), induces apoptosis in thymocytes. Similar data have been obtained in other cell types, including leukemic $\mathrm{T}$ cell lines (8) and cytotoxic T lymphocyte-induced target cell killing (9).

We have previously shown that neutrophils isolated from peripheral blood, or inflamed sites, undergo apoptosis constitutively during aging in vitro (10) and there is histological evidence that neutrophils undergo apoptosis at inflamed sites in vivo $(10,11)$. Neutrophil apoptosis determines the uptake of intact neutrophils by macrophages $(10,12)$ and is associated with specific deficits in neutrophil function, including loss of ability to change shape (polarize) on deliberate stimulation (13). It has been proposed, therefore, that apoptosis represents a mechanism for limiting the toxic potential of the neutrophil. Nevertheless, while neutrophils undergo apoptosis constitutively, the rate of apoptosis can itself be modulated. For example, neutrophil apoptosis is delayed by bacterial products and inflammatory mediators, such as FMLP and C5a (14), as well as other receptor-mediated stimuli associated with calcium mobilization and elevation of $\left[\mathrm{Ca}^{2+}\right]_{i}$ during neutrophil activation (15-17). These data raise an interesting paradox, that apoptosis in the neutrophil is inhibited by stimuli increasing $\left[\mathrm{Ca}^{2+}\right]_{i}$, whilst this event has been shown to trigger apoptosis in other cells.

We therefore examined the effects of modulation of $\left[\mathrm{Ca}^{2+}\right]_{\mathrm{i}}$ upon subsequent apoptosis in neutrophils in vitro, using calcium ionophores, as used in previous studies $(5,6)$. We demonstrated that incubation of neutrophils with calcium ionophores (A23187, 4-bromo-A23187, and ionomycin) dramatically retarded neutrophil apoptosis without inducing cell necrosis. We observed that delay of apoptosis was associated with prolongation of functional lifespan of the neutrophil, assessed by stimulated shape change and was also associated with a corresponding delay in macrophage recognition. Conversely, neutrophil apoptosis was promoted by chelation of intracellular calcium with bis-(o-aminophenoxy)- $N, N, N, N^{\prime}$-tetraacetic acid (BAPTA) acetoxymethyl ester (AM) or use of a calmodulin inhibitor, W-7, with a corresponding reduction in neutrophil function and increase in macrophage recognition. Measurements of $\left[\mathrm{Ca}^{2+}\right]_{i}$ were used to examine changes in $\left[\mathrm{Ca}^{2+}\right]_{i}$ in neutrophil populations during aging in vitro and after treatment with ionophores and BAPTA/AM. Measurements of in-

1. Abbreviations used in this paper: BAPTA/AM, bis-( $o$-aminophenoxy)- $N, N, N^{\prime}, N^{\prime}$-tetraacetic acid/acetoxymethyl ester; BCECF, $2^{\prime}, 7^{\prime}$ bis-(carboxyethyl)-5(6')-carboxyfluorescein; $\left[\mathrm{Ca}^{2+}\right]_{i}$, intracellular free calcium; $\mathrm{M} \phi$, macrophages; $\mathrm{pH}_{\mathrm{i}}$, intracellular $\mathrm{pH}$. 
tracellular $\mathrm{pH}\left(\mathrm{pH}_{\mathrm{i}}\right)$ were also performed. Transient elevation of $\left[\mathrm{Ca}^{2+}\right]_{i}$ resulted in prolonged inhibition of neutrophil apoptosis. Moreover, BAPTA/AM was able to prevent both the elevation of $\left[\mathrm{Ca}^{2+}\right]_{i}$ and the inhibition of apoptosis produced by ionophore.

\section{Methods}

Materials. All chemicals used were from Sigma Chemical Co. (Poole, United Kingdom) unless otherwise indicated and were of the highest grade purity available. Percoll and Ficoll were obtained from Pharmacia Fine Chemicals, Piscataway, NJ, sodium citrate from Pharma Hameln GmbH, Hanover, Germany. Culture media (HBSS, Iscove's DMEM) and supplements ( $100 \mathrm{U} /$ liter penicillin and streptomycin) were purchased from Gibco Laboratories, Grand Island, NY. Sterile tissue culture plastic ware was purchased from Falcon Plastics, Cockeysville, MD. Fura-2 acetoxymethyl ester (fura-2/AM), [2',7'bis-(carboxyethyl)-5(6')-carboxyfluorescein pentaacetoxymethyl)ester] (BCECF/AM), BAPTA/AM, 4-bromo-A23187, and ionomycin were obtained from Calbiochem (Novabiochem, Nottingham, United Kingdom). A23187 was purchased from Boehringer Mannheim (Lewes, United Kingdom).

Neutrophil isolation and culture. Neutrophil granulocytes were isolated from the peripheral blood of normal human volunteers by dextran sedimentation followed by centrifugation through discontinuous plasma-Percoll gradients as previously described $(10,18)$. These techniques minimize activation or "priming" of neutrophils (18) and yield granulocytes of $>98 \%$ purity on May-Giemsa-stained cytopreps. Eosinophil "contamination" of neutrophil fractions was always $<2 \%$. Cells were suspended at concentrations of $5 \times 10^{6} / \mathrm{ml}$ in Iscove's DME with $10 \%$ autologous platelet-rich, plasma-derived serum and with penicillin and streptomycin ( $100 \mathrm{U} /$ liter $)$. The "age" of neutrophils in culture was calculated designating this stage as time 0 . Neutrophils were incubated at $37^{\circ} \mathrm{C}$ in a $5 \% \mathrm{CO}_{2}$ atmosphere and were harvested from culture at various time points thereafter.

Treatment of neutrophils. Cells were incubated in the presence or absence of a variety of potential modulators of apoptosis. These included the calcium ionophores A23187, 4-bromo-A23187 (19), and ionomycin; the calmodulin antagonist W-7 [N(6-aminohexyl)-5chloro-1-naphthalene sulfonamide, $\mathrm{HCl}](20)$ and BAPTA/AM, which chelates intracellular calcium (21). Stock solutions of W-7 were prepared in methanol (final concentration of methanol $0.05 \%$, vol/ $\mathrm{vol}$ ). Stock solutions of all other compounds were prepared in DMSO (all final DMSO concentrations $<0.01 \%$, vol $/ \mathrm{vol}$ ). Aliquots were diluted before each experiment in Iscove's DME. Preliminary experiments confirmed that these concentrations of solvents did not increase cell necrosis or modulate the rate of neutrophil apoptosis (data not shown).

Assessment of cell viability and morphology. At time 0 and then at subsequent time points as indicated in Results, cells were removed from culture and counted on a hemocytometer. Cell necrosis was assessed by trypan blue exclusion and viability always exceeded $98 \%$, except where indicated below. Cell loss during culture was assessed by counting on a hemocytometer and was minimal $(<1 \%)$. Cytocentrifuge preparations were fixed in methanol and stained (May-Giemsa stain) for light microscopic evaluation of apoptosis, which previous studies show to correlate closely with electron microscopy and DNA electrophoresis (10). The percentage of cells demonstrating the highly characteristic light microscopic appearances of apoptosis was assessed by counting $>1,000$ cells/slide. This was further confirmed by demonstration of a characteristic "ladder-pattern" of chromatin fragmentation.

Assay of neutrophil change of shape on stimulation. Neutrophil ability to change shape upon stimulation was assessed using a previously described method (18). Neutrophils were incubated at $37^{\circ} \mathrm{C}$ for $15 \mathrm{~min}$ in the presence of FMLP $(100 \mathrm{nM})$. The cells were then fixed by addition of an equal volume of $2 \%$ glutaraldehyde and the percent- age of cells that had undergone change of shape was assessed by counting ( $>500$ cells). We have previously shown that apoptosis is associated with loss of ability to change shape upon stimulation (13).

Chromatin fragmentation assays. The presence of chromatin fragmentation in aged neutrophils was assessed using a modification of a method previously described for thymocytes (22). Briefly, aged neutrophils were washed twice in HBSS, then lysed with NTE $(100 \mathrm{mM} \mathrm{NaCl}$, $10 \mathrm{mM}$ Tris, $1 \mathrm{mM}$ EDTA) buffer, $\mathrm{pH} 8$, containing $1 \%$ SDS and proteinase $\mathrm{K}(0.2 \mathrm{mg} / \mathrm{ml})$. After incubation at $37^{\circ} \mathrm{C}$ for $12 \mathrm{~h}$, samples were extracted twice with $1: 1(\mathrm{vol} / \mathrm{vol})$ phenol and chloroform:isoamylalcohol $(24: 1, \mathrm{vol} / \mathrm{vol})$. Samples were then precipitated in $80 \%$ ( $\mathrm{vol} / \mathrm{vol}$ ) ethanol at $-20^{\circ} \mathrm{C}$. The DNA was dissolved in $12 \mu \mathrm{l} \mathrm{TBE}(89$ $\mathrm{mM}$ Tris, $89 \mathrm{mM}$ boric acid, $2 \mathrm{mM}$ EDTA) buffer, $\mathrm{pH} 8.4$, and to each sample was added $3 \mu$ l loading buffer containing $15 \%$ (wt/vol) Ficoll $400,0.5 \%$ (wt/vol) SDS, $50 \mathrm{mM}$ EDTA, $0.05 \%$ (wt/vol) bromphenol blue and $0.05 \%$ (vol/vol) xylene cyanol in TBE buffer. The samples, together with $\lambda$ DNA (EcoRI) size markers, were loaded onto a $1 \%$ ( wt/vol) agarose gel containing ethidium bromide $(30 \mu \mathrm{g} / \mathrm{ml})$ and electrophoresed at $50 \mathrm{~V}$ for $3 \mathrm{~h}$ then viewed with ultraviolet light.

Macrophage-neutrophil interaction assay. Recognition and ingestion of aged neutrophils by macrophages $(\mathrm{M} \phi)$ matured from human

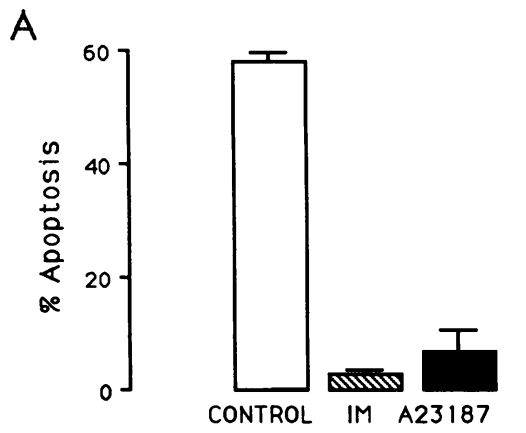

Figure 1. The effects of the calcium ionophores A23187 and ionomycin upon the rate of neutrophil apoptosis, macrophage ingestion of neutrophils, and neutrophil function in vitro. In five experiments, neutrophils were incubated in the presence or absence of the calcium ionophores ionomycin ( 10 $\mu \mathrm{M})$ and $\mathrm{A} 23187$ ( 1 $\mu \mathrm{M}) .(A)$ After $20 \mathrm{~h}$ in culture both ionomycin (hatched bar) and A23187 (solid bar) had greatly retarded apoptosis compared with untreated cells (open bar). $P<0.001$ in both cases. (B) At $20 \mathrm{~h}$ ionomycin (hatched bar) and A23187 (filled bar) had significantly reduced the percentage of macrophages ingesting neutrophils $(P<0.001$ in both cases). $(C)$ Similar modulation of neutrophil ability to undergo stimulated shape change at $20 \mathrm{~h}$ with ionomycin and $\mathrm{A} 23187(P<0.01$ in both cases). Assessment of freshly isolated neutrophils ( time 0 ) in three of the five experiments showed apoptosis of $0.9 \pm 0.8 \%$, macrophage recognition of $0.7 \pm 0.5 \%$, and stimulated shape change of

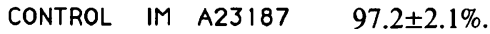


Table I. Effects of Varying Concentrations of A23187 upon Apoptosis and Cell Viability (Expressed as a Percentage of the Control Population) after $20 \mathrm{~h}$ in Culture

\begin{tabular}{lcccccc}
\hline & \multicolumn{5}{c}{$\mathrm{A} 23187$} \\
\cline { 3 - 7 } Treatment & Control & $0.1 \mu \mathrm{M}$ & $0.5 \mu \mathrm{M}$ & $1 \mu \mathrm{M}$ & $2 \mu \mathrm{M}$ & $5 \mu \mathrm{M}$ \\
\hline $\begin{array}{c}\text { Apoptosis } \\
(\text { Mean } \pm \text { SE\%) } \\
\begin{array}{c}\text { Viability } \\
(\text { Mean } \pm \text { SE\%) }\end{array}\end{array}$ & $45.2 \pm 1.6$ & $45.2 \pm 4$ & $46.9 \pm 2.4$ & $3.0 \pm 0.9$ & $4.7 \pm 0.8$ & $4.9 \pm 1.3$ \\
\hline
\end{tabular}

Results shown are means of three experiments, each counted in triplicate.

peripheral blood monocytes over $7 \mathrm{~d}$ was assayed as previously described (10). Briefly, neutrophils were washed in HBSS, resuspended at $1 \times 10^{6} / \mathrm{ml}$ in HBSS, and $1 \mathrm{ml}$ of suspension was added to each well of adherent $\mathrm{M} \phi$ cultures in 24-well plates. After $30 \mathrm{~min}$ incubation at $37^{\circ} \mathrm{C}$ in a $5 \% \mathrm{CO}_{2}$ atmosphere, the wells were vigorously washed with cold $\left(4^{\circ} \mathrm{C}\right)$ saline and fixed with $2 \%$ glutaraldehyde in PBS. To identify ingested neutrophils, wells were then stained for myeloperoxidase using hydrogen peroxide and dimethoxybenzidine as substrate. The interaction was quantified by counting, under light microscopy, the proportion of $\mathbf{M} \phi$ containing myeloperoxidase-positive cells in five randomly selected fields. A minimum of $500 \mathrm{M} \phi$ were assessed per well and the percentage ingesting neutrophils recorded. A minimum of three wells were counted per treatment and all neutrophil samples were handled in the same way, regardless of their time in culture. Fresh and aged control (nonmodulated) neutrophils were included as additional controls.

Determination of cytosolic calcium levels $\left[\mathrm{Ca}^{2+}\right]_{i} \cdot\left[\mathrm{Ca}^{2+}\right]_{i}$ was assayed using a modification of the method described by Karnad et al. (23). Briefly, neutrophils were removed from culture, washed three times in HBSS without phenol red, and then incubated with fura-2/ AM (final concentration $2 \mu \mathrm{M}$ ) for $30 \mathrm{~min}$ at $37^{\circ} \mathrm{C}$. After washing away fura-2/AM and allowing a further $10 \mathrm{~min}$ for optimal deesterification, neutrophils were resuspended at $2 \times 10^{6} / \mathrm{ml}$ in HBSS without phenol red. Fluorescence was determined using a spectrofluorophotometer (Shimadzu RF5000; V.A. Howe Ltd., London, United Kingdom) with dual wavelength excitation ( 336 and $366 \mathrm{~nm}$ ) and emission at 510 $\mathrm{nm}$. Cells were stirred continuously at $37^{\circ} \mathrm{C} .\left[\mathrm{Ca}^{2+}\right]_{i}$ was calculated using Labtime DWT software (V.A. Howe Ltd., London, United Kingdom) from the relationship $\left[\mathrm{Ca}^{2+}\right]_{\mathrm{i}}=K_{\mathrm{d} .}\left(R-R_{\min }\right) /\left(R_{\max }\right.$ $-\mathrm{R}) \cdot \beta(24)$ : where $\left[\mathrm{Ca}^{2+}\right]_{\mathrm{i}}$ is the cytosolic calcium concentration, $R$ is the ratio of fluorescence obtained at 336 and $366 \mathrm{~nm}$ in the cuvette before calibration, $R_{\max }$ is the ratio obtained in the presence of saturating $\left[\mathrm{Ca}^{2+}\right]_{\mathrm{i}}$ (after treatment with $50 \mu \mathrm{M}$ digitonin), $R_{\min }$ is the ratio obtained in the absence of calcium (addition of 25 mM EGTA), $K_{\mathrm{d}}$ is the dissociation constant for fura- 2 , taken as $224 \mathrm{nM}$ at $37^{\circ} \mathrm{C}(24)$, and $\beta$ is the fluorescence ratio at $366 \mathrm{~nm}$ of cells in the absence and presence of calcium. The calcium ionophore, 4-bromo-A23187, was added directly to neutrophil suspensions in the cuvette in the fluorimeter (final concentration 0.1-10 $\mu \mathrm{M}$ ). In the time course experiments, where 4bromo-A23187 was added to the neutrophil suspensions in culture, the cells were removed from culture at the time points indicated and then washed twice before loading with fura-2/AM. 4-bromo-A23187 is nonfluorescent at the wavelengths used to measure $\left[\mathrm{Ca}^{2+}\right]_{i}$ using fura-2 (19). In other experiments, cells were preincubated with the calcium chelator BAPTA/AM (for $30 \mathrm{~min}$ at $37^{\circ} \mathrm{C}$ ) and again washed twice before loading with fura-2/AM.

Determination of $\mathrm{pH}_{i} . \mathrm{pH}_{\mathrm{i}}$ was measured by a method similar to that described by Hartshorn et al. (25), using the acetoxymethyl ester of the fluorescent probe BCECF. Neutrophils were incubated with BCECF/AM (final concentration $5 \mu \mathrm{M}$ ) for $30 \mathrm{~min}$ at $37^{\circ} \mathrm{C}$, washed, and resuspended at $2 \times 10^{6} / \mathrm{ml}$ in HBSS without phenol red. Fluorescence was determined by dual ratio quantitation, with excitation at 506 and $455 \mathrm{~nm}$ and emission at $530 \mathrm{~nm}$. The fluorescence ratio obtained was related to $\mathrm{pH}_{\mathrm{i}}$ by linear regression analysis based on $\mathrm{pH}$ standards as described (25), the relationship between fluorescence and $\mathrm{pH}_{\mathrm{i}}$ being strictly linear only between $\mathrm{pH} 6.5$ and 7.5. As with the $\left[\mathrm{Ca}^{2+}\right]_{\mathrm{i}}$ measurements, 4-bromo-A23187 (final concentration $1-10 \mu \mathrm{M}$ ) was added directly to neutrophil suspensions in the cuvette. In other experiments, cells were preincubated with BAPTA/AM ( for $30 \mathrm{~min}$ at $37^{\circ} \mathrm{C}$ ) and washed twice before loading with BCECF/AM.

Statistical methods. Neutrophil apoptosis, shape change ability, and cytosolic calcium measurements are given as mean \pm SEM. Con-
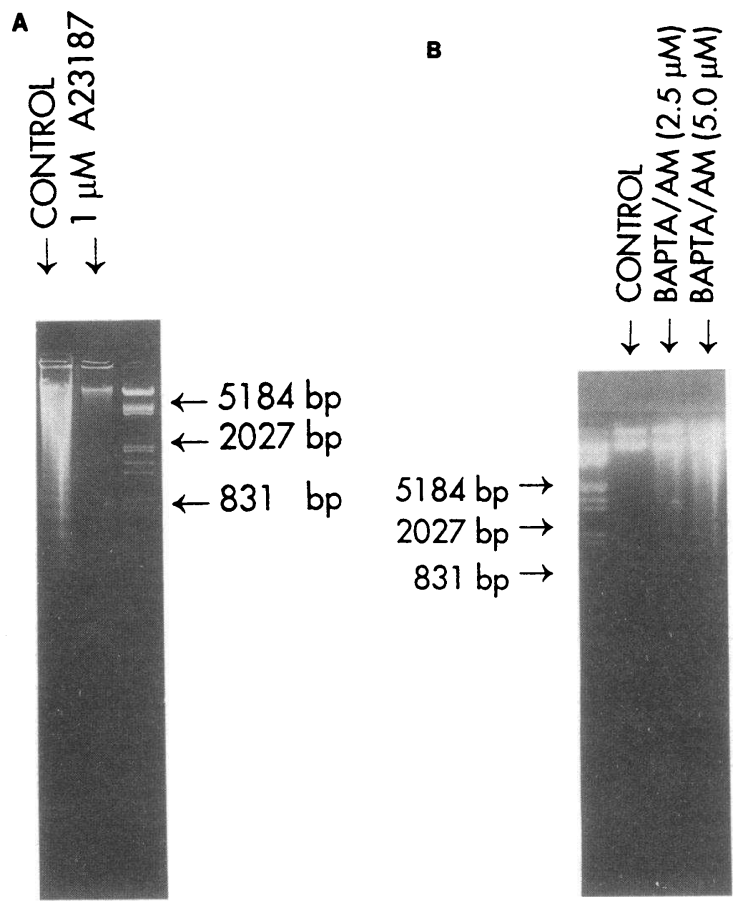

Figure 2. Modulation of endogenous endonuclease activity by ionophore and BAPTA/AM. Electrophoresis of DNA obtained from untreated cells and cells treated with A23187 $(1 \mu \mathrm{M})$ for $20 \mathrm{~h}$, and BAPTA/AM $(2.5 \mu \mathrm{M}$ and $5.0 \mu \mathrm{M})$ for $8 \mathrm{~h}$. $(A)$ A23187 treatment prevented appearance of the characteristic ladder pattern of apoptosis which was present in untreated cells at $20 \mathrm{~h}$ (after a 20 -h incubation, apoptosis was $45.2 \pm 1.6 \%$ in control and $3.0 \pm 0.9 \%$ in A23187-treated cells $[P<0.001]$, having been $0.9 \pm 0.8 \%$ in freshly isolated cells). The right-hand lane contains standard DNA markers. $(B)$ Conversely, DNA from BAPTA/AM-treated cells exhibited a ladder pattern at $8 \mathrm{~h}$ which was absent from control DNA. The left-hand lane contains standard DNA markers. (After an 8-h incubation, $2.5 \mu \mathrm{M}$ BAPTA/AM increased apoptosis to $18.8 \pm 5.1 \%$ [ mean \pm SEM, $n$ $=4, P<0.02$ ] and $5 \mu \mathrm{M}$ BAPTA $/$ AM to $45.0 \pm 8.2 \%[P<0.001]$ compared with $1.0 \pm 0.5 \%$ in the freshly isolated [time 0 ] cells and $9.8 \pm 3.9 \%$ in parallel control populations at $8 \mathrm{~h}$ ). 

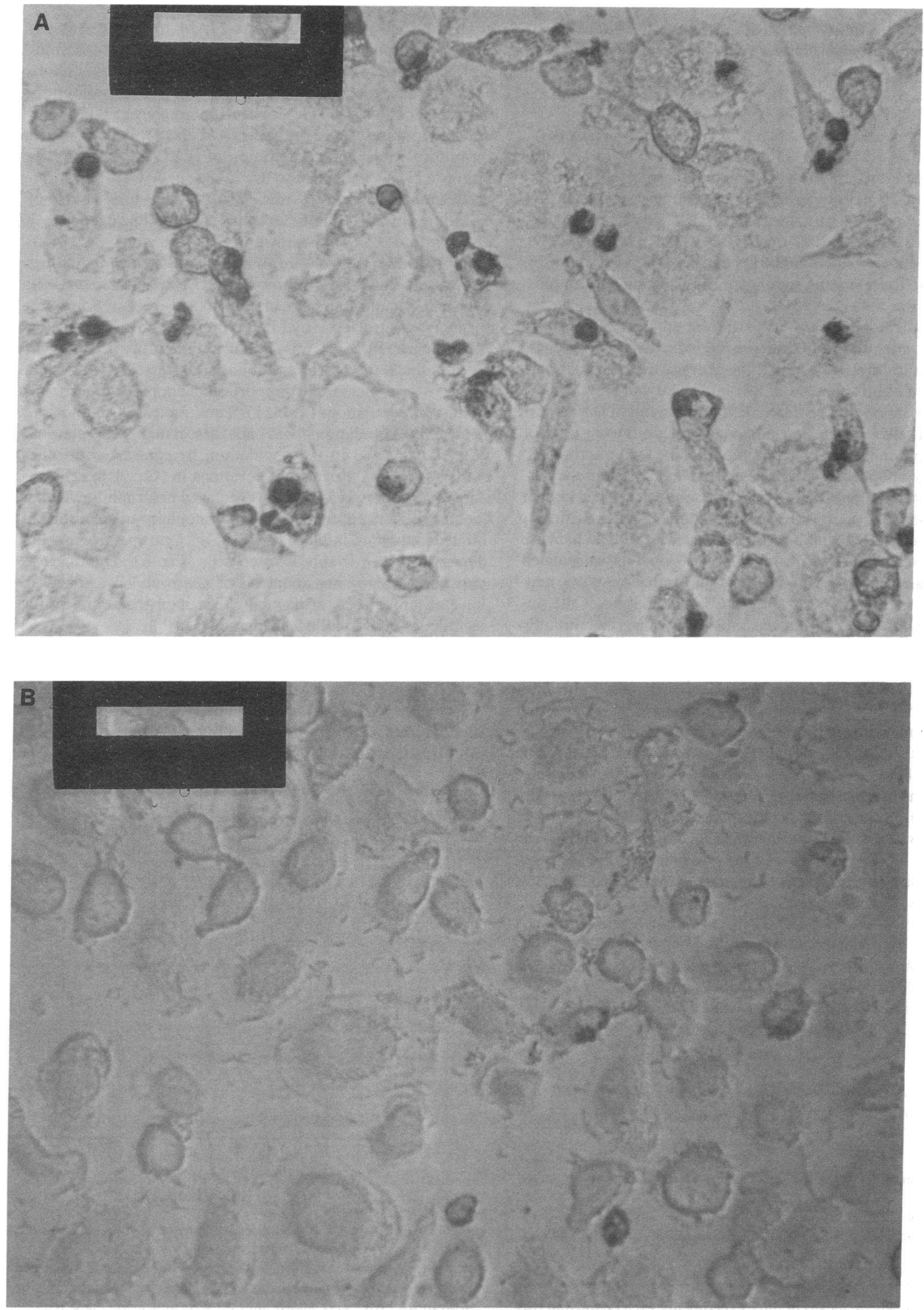

Figure 3. Modulation of macrophage phagocytosis of aging neutrophils. $(A)$ Recognition and ingestion of 20-h control (untreated) neutrophils by macrophages. A large number of myeloperoxidase-stained neutrophils can be seen within adherent macrophages. $(B)$ 20-h neutrophils treated with $1 \mu \mathrm{M}$ A23187, with almost complete inhibition of apoptosis ( see text) are not recognized and ingested by macrophages. Scale bar $=25 \mu \mathrm{m}$. 
trol, ionophore-treated, W-7-treated, and BAPTA-treated cells from the same neutrophil population were compared using paired $t$ tests.

\section{Results}

Calcium ionophores inhibit neutrophil apoptosis. Exposure of neutrophils to A23187 $(1 \mu \mathrm{M})$ and ionomycin $(10 \mu \mathrm{M})$ produced a dramatic inhibition of the light microscopic features of apoptosis at $20 \mathrm{~h}$, compared with the control population. In five experiments, apoptosis was $58.0 \pm 1.7 \%$ in control populations, $6.7 \pm 3.7 \%$ in A23187-treated $(P<0.001)$, and $2.9 \pm 0.5 \%$ in ionomycin-treated $(P<0.001)$ neutrophil populations at 20 $\mathrm{h}$ (Fig. 1). There was no significant cell necrosis (trypan blue exclusion was always $>95 \%$ ). A23187 produced a concentration-dependent inhibition of neutrophil apoptosis (Table I). The light microscopical evidence of reduced apoptosis was confirmed in three ways. First, the characteristic "ladder-pattern" upon electrophoresis of low molecular weight DNA (4) was absent in ionophore-treated cells but present in DNA from untreated cells (Fig. 2). Secondly, in interactions using control and ionophore-treated cells, inhibition of the light microscopic changes of apoptosis was correlated with a decrease in the percentage of macrophages ingesting neutrophils, which is known to be dependent upon neutrophil apoptosis (Figs. $1 B$ and 3). Thirdly, inhibition of apoptosis was associated with an increase in the percentage of neutrophils able to undergo stimulated shape change; previous studies have shown that apoptotic neutrophils lose this property (Fig. $1 C$ ). Modulation of the nuclear features of apoptosis was thus occurring concomitantly with the functional and cell surface changes of apoptosis.

$B A P T A / A M$ promotes neutrophil apoptosis. The inhibitory effect of calcium ionophore suggested that $\mathrm{Ca}^{2+}$ chelation might promote apoptosis in aging neutrophils. This was tested by studying neutrophils after $8 \mathrm{~h}$ in culture, so that increases in apoptosis might more easily be detected than at later time points, where a greater proportion of cells would already have undergone this process. BAPTA/AM (a chelator of intracellular $\mathrm{Ca}^{2+}$ ) produced a concentration-dependent promotion of apoptosis ( Table II), at concentrations that did not induce cell necrosis, in keeping with our previous observation (10) that neutrophils remain intact for some hours after the onset of apoptosis. In three experiments, BAPTA/AM $(2.5 \mu \mathrm{M})$ significantly increased apoptosis to $18.8 \pm 5.1 \%$ at $8 \mathrm{~h}$, compared with $9.8 \pm 3.9 \%$ in parallel control populations $(P<0.02)$. A ladder pattern of chromatin fragmentation was demonstrated in DNA from BAPTA-treated but not from control cells (Fig. 2).

Culture of neutrophils with ionophore induces a transient rise in $\left[\mathrm{Ca}^{2+}\right]_{i}$. Cytosolic $\mathrm{Ca}^{2+}$ levels, $\left[\mathrm{Ca}^{2+}\right]_{i}$, were measured

Table II. Effects of Varying Concentrations of BAPTA/AM upon Apoptosis and Cell Viability after $8 \mathrm{~h}$ in Culture

\begin{tabular}{lccccc}
\hline & & \multicolumn{4}{c}{ BAPTA/AM } \\
\cline { 3 - 6 } Treatment & Control & $0.5 \mu \mathrm{M}$ & $1.0 \mu \mathrm{M}$ & $2.5 \mu \mathrm{M}$ & $5.0 \mu \mathrm{M}$ \\
\hline Apoptosis & & & & & \\
$($ Mean \pm SEM\%) & $9.8 \pm 3.9$ & $10.1 \pm 3.0$ & $9.5 \pm 3.6$ & $18.8 \pm 5.1$ & $45.0 \pm 8.2$ \\
Viability & $>99 \%$ & $>99 \%$ & $>99 \%$ & $>99 \%$ & $96.5 \%$ \\
\hline
\end{tabular}

Results shown are means of three experiments, each counted in triplicate. using the $\mathrm{Ca}^{2+}$-sensitive dye fura-2/AM in neutrophils exposed to various concentrations of the ionophore 4-bromoA23187. These ranged from $0.5 \mu \mathrm{M}$, below which ionophore had no effect upon apoptosis, to $5.0 \mu \mathrm{M}$ which profoundly inhibited apoptosis at $20 \mathrm{~h}$. Concentrations above $5.0 \mu \mathrm{M}$ were not used as these caused cell necrosis (Table I). We observed a concentration-dependent elevation of $\left[\mathrm{Ca}^{2+}\right]_{\mathrm{i}}$ levels when 4bromo-A23187 was added to the cuvette and $\left[\mathrm{Ca}^{2+}\right]_{\mathrm{i}}$ continuously monitored over $10 \mathrm{~min}$ (Fig. 4). The time course of elevation of $\left[\mathrm{Ca}^{2+}\right]_{i}$, in neutrophils exposed throughout to 1 $\mu \mathrm{M}$ 4-bromo-A23187, is shown in Fig. 5. Resting $\left[\mathrm{Ca}^{2+}\right]_{i} \mathrm{val}-$ ues of $100 \mathrm{nM}$ or below were obtained, consistent with findings in other studies (15). 4-bromo-A23187 caused a rapid rise in cytosolic calcium to a peak of $350-400 \mathrm{nM}$ within $5 \mathrm{~min}$, returning to control levels by $1 \mathrm{~h}$. It is important to note that after $20 \mathrm{~h}$ in culture $\left[\mathrm{Ca}^{2+}\right]_{\mathrm{i}}$ was similar to that at the beginning of culture, for both control and ionophore-treated cells, despite the large differences in the proportion of apoptotic neutrophils in the two populations (Table I). Thus, increased apoptosis in neutrophil populations was not associated with elevated $\left[\mathrm{Ca}^{2+}\right]_{\mathrm{i}}$ measured in the population, by contrast with other studies reporting progressive elevations in $\left[\mathrm{Ca}^{2+}\right]_{i}$ in cells undergoing apoptosis ( 5-7). However, aged neutrophils, whether highly apoptotic, untreated cells, or ionophore-treated, still exhibited ionophore-induced rises in $\left[\mathrm{Ca}^{2+}\right]_{\mathrm{i}}$ comparable to those demonstrated in freshly isolated cells (Fig. 6). This suggests that neither aging nor apoptosis of neutrophils was likely to have an unforeseen, artifactual effect upon the ability of the techniques used to follow changes in $\left[\mathrm{Ca}^{2+}\right]_{i}$.

Stimuli altering $\left[\mathrm{Ca}^{2+}\right]_{\mathrm{i}}$ in the neutrophil may also modulate intracellular $\mathrm{pH}(25) \cdot \mathrm{pH}_{\mathrm{i}}$ was measured in neutrophils loaded with the fluorescent indicator, BCECF/AM. Resting $\mathrm{pH}_{\mathrm{i}}$ values of $7.37 \pm 0.03$ were obtained $(n=8)$, comparable to other studies (25). In three experiments, $\mathrm{pH}_{\mathrm{i}}$ was measured after treatment of cells with 4-bromo-A23187. Over the time

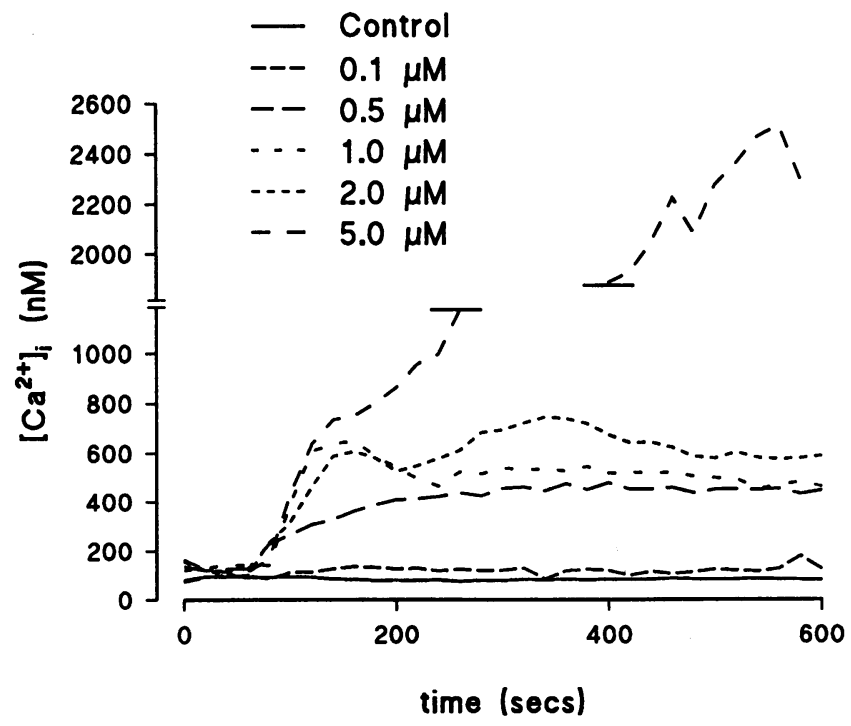

Figure 4. Measurement of cytosolic calcium levels in freshly isolated neutrophils in response to different concentrations of 4-bromoA23187. Cytosolic calcium measurements ( $\mathrm{nM}$ ) in fura-2-loaded, freshly isolated neutrophils over $10 \mathrm{~min}$. Various concentrations of 4-bromo-A23187 were added after $60 \mathrm{~s}$, as indicated. These data, from a single experiment, are representative of three experiments. 


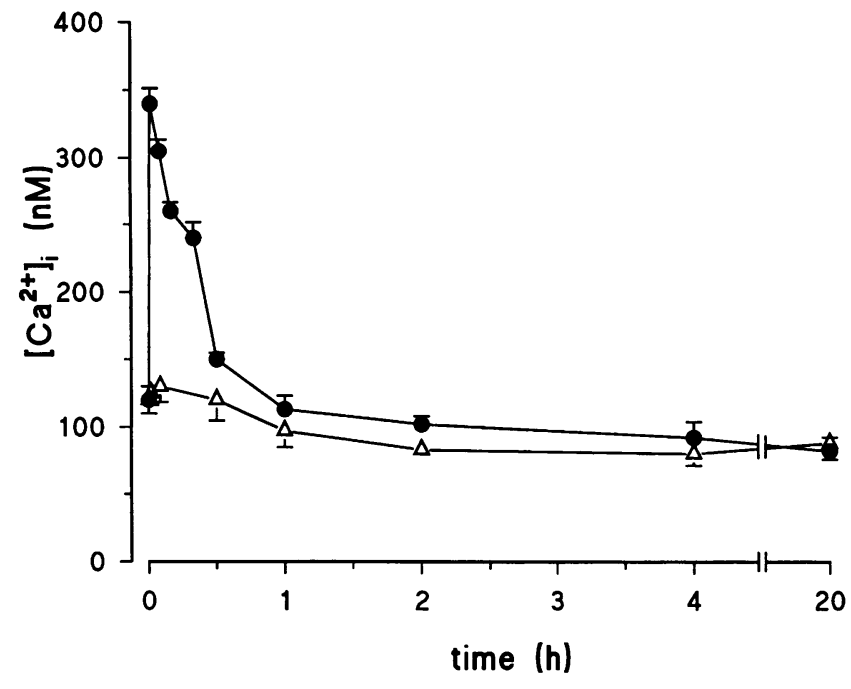

Figure 5. Time course of cytosolic calcium levels in control and $1 \mu \mathrm{M}$ 4-bromo-A23187-treated cells. Cytosolic calcium ( $\mathrm{nM}$, mean $\pm \mathrm{SE}$ of triplicate measurements) in control $(\Delta)$ and $1 \mu \mathrm{M}$ 4-bromoA23187-treated $(\bullet)$ neutrophils plotted against time (hours). Time 0 is immediately before addition of ionophore. At $20 \mathrm{~h}$, apoptosis was $71 \%$ in the control population and $23 \%$ in the ionophore-treated cells. These data, from a single experiment, are representative of three experiments.

course of the elevation of $\left[\mathrm{Ca}^{2+}\right]_{i}$, no change in $\mathrm{pH}_{\mathrm{i}}$ was observed with $1 \mu \mathrm{M}$ 4-bromo-A23187, a concentration both profoundly inhibiting apoptosis and elevating $\left[\mathrm{Ca}^{2+}\right]_{i}$ (Fig. 7). Furthermore, no alteration in $\mathrm{pH}_{\mathrm{i}}$ was seen at later time points up to $3 \mathrm{~h}$ (data not shown). However, higher concentrations of 4-bromo-A23187 ( $5 \mu \mathrm{M}$ and $10 \mu \mathrm{M}$ ), which were associated with loss of neutrophil viability ( Table I), did cause intracellular alkalinization (Fig. 7).

BAPTA/AM blocks the ionophore-induced $\mathrm{Ca}^{2+}$ spike and inhibition of apoptosis. Neutrophil suspensions were preloaded with BAPTA/AM for $30 \mathrm{~min}$ at $37^{\circ} \mathrm{C}$ at a range of concentrations from 0.5 to $5 \mu \mathrm{M}$ and $\left[\mathrm{Ca}^{2+}\right]_{i}$ measured over $4 \mathrm{~min}$ (Fig. 7). BAPTA/AM at concentrations $>5 \mu \mathrm{M}$ caused significant cell necrosis (data not shown). Concentrations of $<2.5 \mu \mathrm{M}$ had no effect upon cell necrosis or upon the percentage of apoptotic cells after $8 \mathrm{~h}$ in culture ( Table II). A concentration of $2.5 \mu \mathrm{M}$ BAPTA/AM, which had been shown to increase the rate of neutrophil apoptosis, did not affect resting $\left[\mathrm{Ca}^{2+}\right]_{\mathrm{i}}$ but prevented elevation of $\left[\mathrm{Ca}^{2+}\right]_{i}$ in response to addition of ionophore to the cuvette (Fig. 8) $5 \mu$ M BAPTA/AM, which caused a greater promotion of apoptosis, lowered resting $\left[\mathrm{Ca}^{2+}\right]_{i}$.

Although loading of cells with BAPTA/AM necessarily releases acid because of cleavage of the parent ester $(25,26)$, concentrations of BAPTA/AM of $2.5 \mu \mathrm{M}$ or below did not alter $\mathrm{pH}_{\mathrm{i}}$. In three experiments, $\mathrm{pH}_{\mathrm{i}}$ was $7.37 \pm 0.04$ in control cells, $7.45 \pm 0.06$ in cells incubated with $1 \mu \mathrm{M}$ BAPTA/AM, and $7.30 \pm 0.03$ in cells incubated with $2.5 \mu \mathrm{M}$ BAPTA/AM. 5 $\mu \mathrm{M}$ BAPTA/AM caused a slight lowering of $\mathrm{pH}_{\mathrm{i}}$ to $7.25 \pm 0.04$. $10 \mu \mathrm{M}$ and $20 \mu \mathrm{M}$ BAPTA / AM lowered $\mathrm{pH}_{\mathrm{i}}$ to $7.12 \pm 0.14$ and $6.83 \pm 0.34$, respectively, comparable to published data (25).

In three further experiments, neutrophils were preincubated for $8 \mathrm{~h}$ in the presence or absence of A23187, BAPTA/ AM, or both compounds. BAPTA/AM prevented elevation of cytosolic calcium in response to 4-bromo-A23187, whether added to the measuring cuvette (Fig. $9 C$ ) or, added together with BAPTA/AM, at the start of the 8-h culture period (Fig. 9 $D)$. In addition, BAPTA/AM prevented the inhibition of apoptosis produced by ionophore. After $8 \mathrm{~h}$, apoptosis was $9.2 \pm 1.2 \%$ in control cells, $1.2 \pm 0.6 \%$ in cells incubated with A23187, 27.0 $\pm 3.3 \%$ in cells incubated with BAPTA/AM, and $20.6 \pm 4.3 \%$ in cells incubated with both A23187 and BAPTA.

$W-7$ promotes neutrophil apoptosis. To investigate a possible role for calmodulin in the effects of calcium ionophore on apoptosis, neutrophils were treated with a calmodulin inhibitor, W-7. Exposure of neutrophils to $\mathrm{W}-7(60 \mu \mathrm{M})$ for $8 \mathrm{~h}$ increased the percentage of apoptotic neutrophils to $24.0 \pm 8.5 \%$ compared with $7.1 \pm 1.0 \%$ in parallel control populations $(P<0.05)$. This promotion of neutrophil apoptosis was associated with corresponding increases in the percentage of macrophages ingesting neutrophils and a reduction in the percentage of neutrophils able to undergo stimulated shape change (Fig. 10). Again, there was no significant cell necrosis in these experiments.

\section{Discussion}

In these studies two calcium ionophores, A23187 and ionomycin, markedly inhibited, in a concentration-dependent manner, the rate of apoptosis (programmed cell death) in neutro-
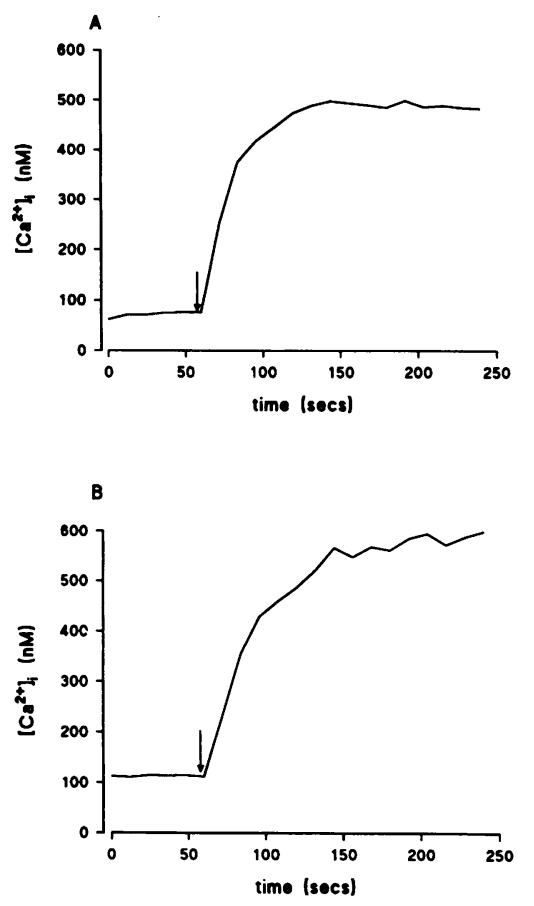

Figure 6. Cytosolic calcium levels in response to further addition of 1 $\mu \mathrm{M}$ 4-bromo-A23187. $(A)$ Fresh neutrophils (0.8\% apoptosis). (B) 20-h control (untreated) neutrophils (54.1\% apoptosis). ( $C$ ) 20-h $1 \mu \mathrm{M}$ 4-bromoA23187-treated neutrophils (19.2\% apoptosis). Cytosolic calcium (nM) measured over $240 \mathrm{~s}$, with $1 \mu \mathrm{M} 4$ bromo-A23187 added at $60 \mathrm{~s}$, as indicated by the arrows. Cell populations obtained from a single donor. These data, from a single experiment, are representative of three experiments. 


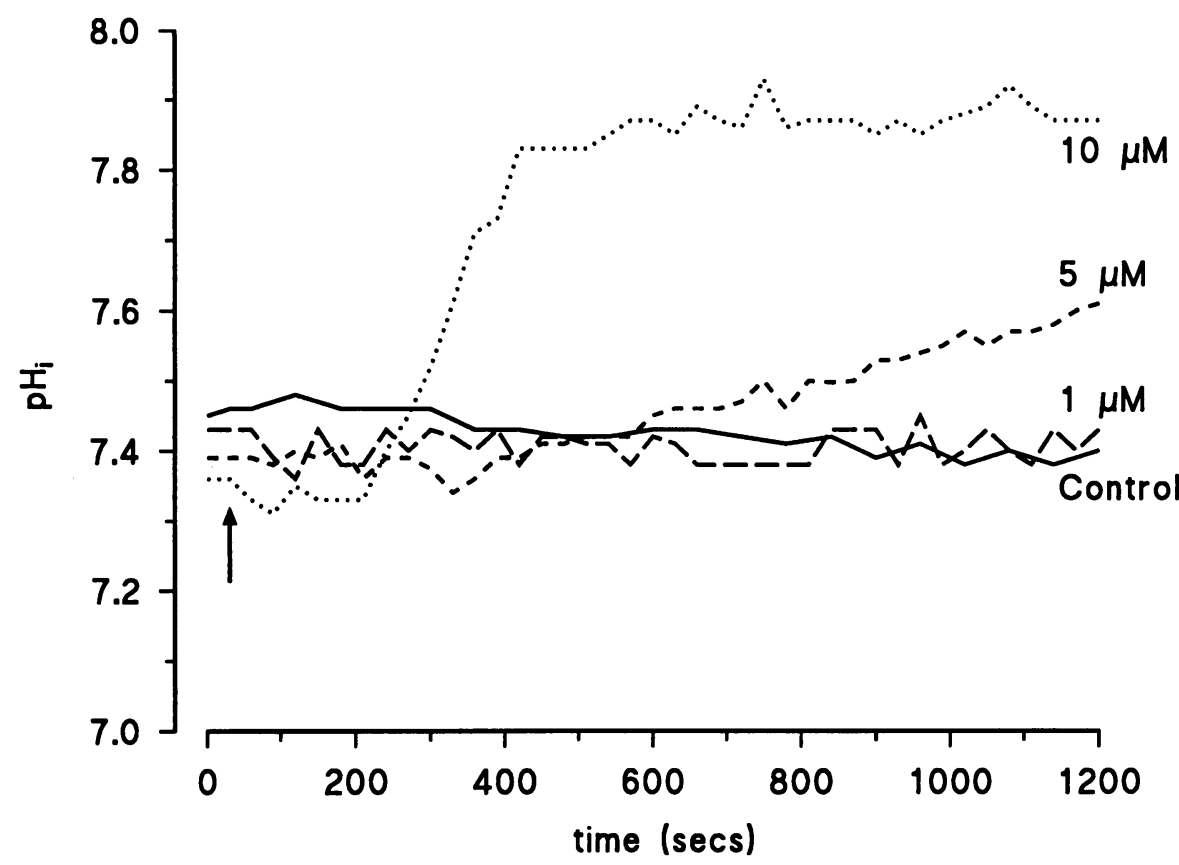

Figure 7. Time course of $\mathrm{pH}_{\mathrm{i}}$ in control and 4-bromo-A23187-treated cells. $\mathrm{pH}_{\mathrm{i}}$ in control neutrophils and neutrophils treated with different concentrations of 4-bromoA23187. Ionophore was added to the cuvette after $30 \mathrm{~s}$ as indicated. Results shown are from a single experiment but are representative of three experiments. phils "aging" in vitro. Conversely, a calcium chelator BAPTA/ AM promoted neutrophil apoptosis, as did a calmodulin inhibitor, W-7. That this was "true" apoptosis was shown by the correlation of nuclear changes of apoptosis (light microscopic appearance and DNA fragmentation) with other changes which have been previously shown to correlate with apoptosis: loss of functional response to stimulation (13) and recognition and ingestion by macrophages (10). These events are determined by apoptosis when it is constitutive and are not dissociated from it in these modulating experiments. The calcium ionophore 4-bromo-A23187 was shown to produce concentration-dependent elevation of $\left[\mathrm{Ca}^{2+}\right]_{i}$ in neutrophil popu-

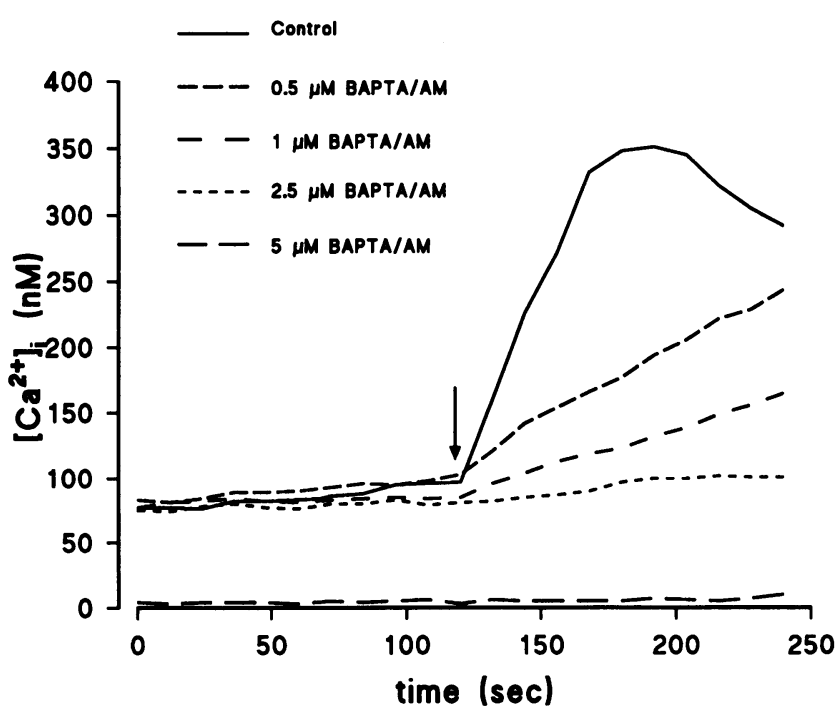

Figure 8. Measurements of cytosolic calcium in response to varying concentrations of BAPTA/AM. Cytosolic calcium (nM) measured in fura-2-loaded, freshly isolated neutrophils over $240 \mathrm{~s}$, the cells having been pretreated with various concentrations of BAPTA/AM for $30 \mathrm{~min}$ at $37^{\circ} \mathrm{C}$. $1 \mu \mathrm{M}$ 4-bromo-A23187 was added at $120 \mathrm{~s}$ as indicated. These data, from a single experiment, are representative of three experiments. lations. The elevation of $\left[\mathrm{Ca}^{2+}\right]_{i}$ was transient, but exerted a marked influence upon subsequent apoptosis and cell death. The relative contributions of intracellular and extracellular sources of $\mathrm{Ca}^{2+}$ were not determined in these studies. The intracellular calcium chelator BAPTA/AM prevented both the elevation of $\left[\mathrm{Ca}^{2+}\right]_{i}$ and the inhibition of apoptosis produced by ionophore. The modulating effects of both ionophore and BAPTA were observed at concentrations which did not alter intracellular $\mathrm{pH}$, although this was observed, together with loss of cell viability, at higher concentrations of both compounds. These data indicate that transient rises in $\left[\mathrm{Ca}^{2+}\right]_{i}$ can have profound and long-lasting effects upon as yet unknown signaling pathways modulating endonuclease activation.

Neutrophil apoptosis leads to functional downregulation and swift phagocytic clearance of senescent "unwanted" neutrophils. Characterization of the mechanisms of neutrophil apoptosis is likely to have important implications for understanding of the lifespan and toxic potential of the neutrophil at inflamed sites. Calcium mobilization and elevation of $\left[\mathrm{Ca}^{2+}\right]_{i}$ are recognized to be important mechanisms in receptor-mediated activation of neutrophils. Physiologically relevant stimuli, such as the chemotactic peptide, FMLP (15), the leukotriene $\mathrm{LTB}_{4}$ (16), and interleukin-1 (17), at concentrations which induce cellular functions such as degranulation $(17,27)$ and respiratory burst $(28)$, produce elevations of $\left[\mathrm{Ca}^{2+}\right]_{i}$ equivalent to those seen in these experiments. The degree of neutrophil functional response does not directly relate to the elevation of cytosolic calcium above resting levels since activation of other signal transduction pathways also occurs (29). However, the importance of elevation of $\left[\mathrm{Ca}^{2+}\right]_{i}$ in neutrophil activation has been shown by the ability of calcium ionophores to induce neutrophil activation, as assessed by superoxide anion generation $(29,30)$ and degranulation $(27,29)$, associated with elevations of $\left[\mathrm{Ca}^{2+}\right]_{i}$ similar to those seen with physiological stimuli.

In other cell types, however, elevated $\left[\mathrm{Ca}^{2+}\right]_{i}$ levels have been implicated in triggering programmed cell death (apoptosis). Apoptosis is a type of cell death that occurs as a normal component of development and of tissue homeostasis $(3,31)$. 

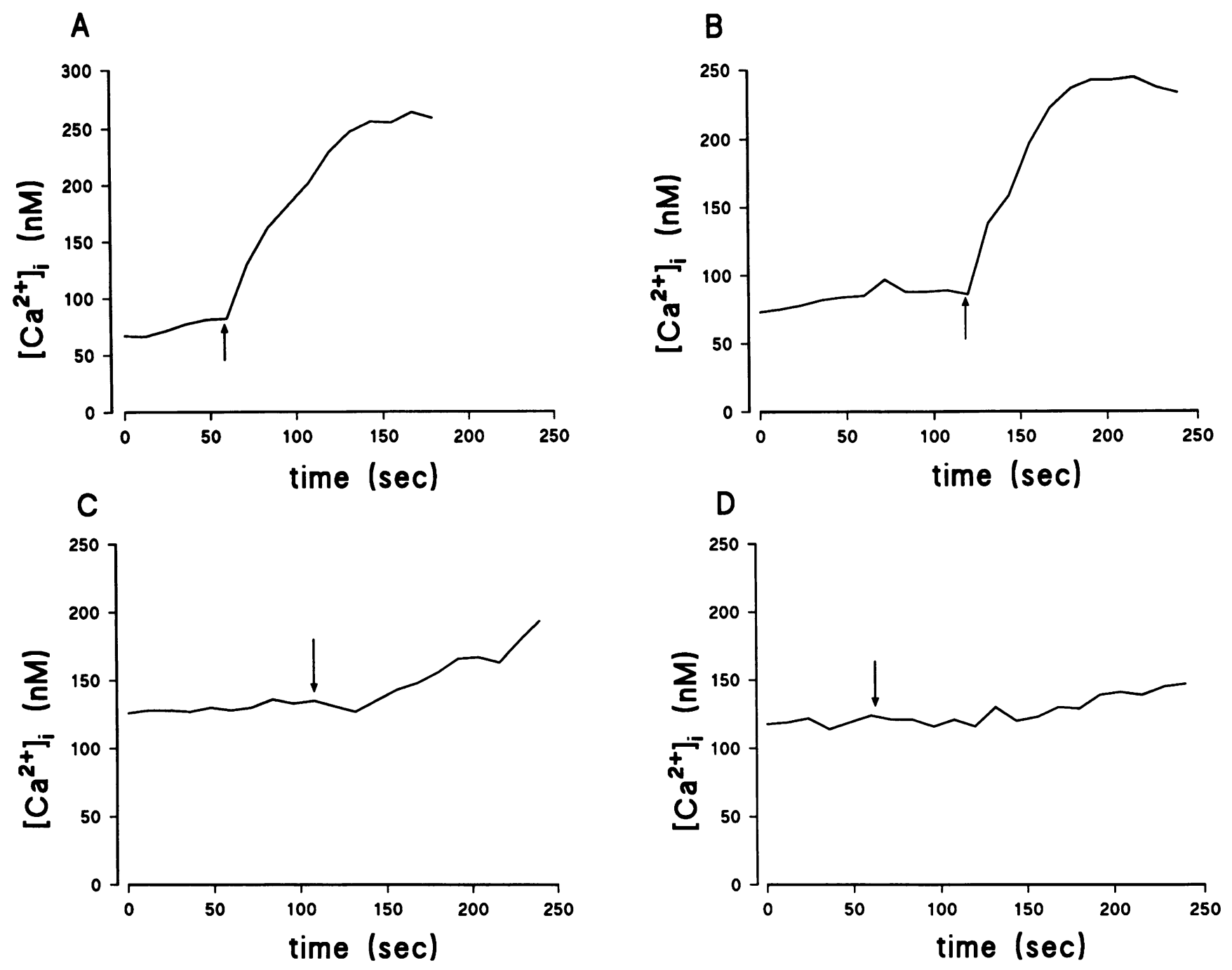

Figure 9. Measurements of resting cytosolic calcium levels and response to $1 \mu \mathrm{M} 4$-bromo A23187 in neutrophils preincubated for $8 \mathrm{~h}$ with

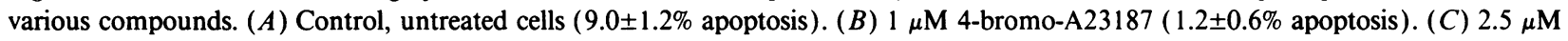
BAPTA/AM (27.0 $\pm 3.3 \%$ apoptosis). (D) $1 \mu \mathrm{M}$ 4-bromo-A23187 and $2.5 \mu \mathrm{M}$ BAPTA/AM (20.6 $\pm 4.3 \%$ apoptosis). $1 \mu \mathrm{M} 4$-bromo-A23187 was added to the cuvette as indicated by the arrows. These data, from a single experiment, are representative of three experiments.
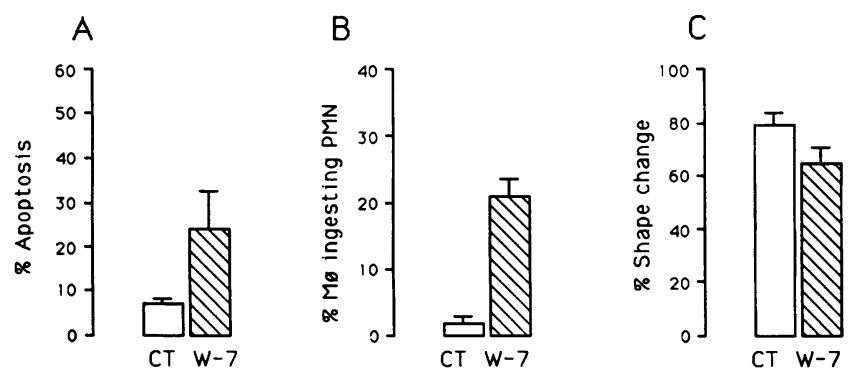

Figure 10. The effect of the calmodulin inhibitor, W-7 $(60 \mu \mathrm{M})$, upon neutrophil apoptosis, macrophage ingestion of neutrophils, and neutrophil function in vitro. In four experiments, neutrophils were incubated in the presence or absence of $\mathrm{W}-7(60 \mu \mathrm{M})$. Assessment of freshly-isolated (time 0 ) neutrophils in three of the four experiments showed $0.7 \pm 0.6 \%$ apoptosis, $0.2 \pm 0.2 \%$ macrophage ingestion, and $98.5 \pm 1.5 \%$ stimulated change of shape. $(A)$ After $8 \mathrm{~h}$ in culture, apoptosis was promoted in W-7-treated compared with untreated neutrophils $(P<0.05)$. (B) At $8 \mathrm{~h}, \mathrm{~W}-7$ had significantly increased macrophage ingestion of neutrophils $(P<0.001)$. (C) Similar modulation of neutrophil ability to undergo change of shape upon stimulation $(P<0.05)$.
A wide range of nucleated cells undergo apoptosis, but the process has been most extensively studied in lymphoid cells. A sterotyped sequence of events, including morphological and biochemical changes, suggests an organized pathway to cell death. Calcium has been implicated at two major stages in this pathway; in the initiation of the apoptotic process and in the final common pathway of activation of a calcium-dependent endonuclease $(2,32)$. Calcium ionophores have been shown to induce apoptosis in rat thymocytes (5), immature mouse thymocytes (33) and in human leukemic T cell lines (8). Cytotoxic $\mathrm{T}$ lymphocyte-induced target cell death has been associated with elevation of target cell $\left[\mathrm{Ca}^{2+}\right]_{\mathrm{i}}$ and similar elevations and subsequent cell death were produced by ionomycin (9). Moreover, elevation of cytosolic calcium has been implicated in the induction of apoptosis by both glucocorticoids (6) and the toxin 2,3,7,8-tetrachlorodibenzo-p-dioxin (34) in immature rat thymocytes. In the latter experiments, the appearance of DNA fragmentation was preceded by elevation of $\left[\mathrm{Ca}^{2+}\right]_{\mathrm{i}}$. Moreover, inhibition of the rise in $\left[\mathrm{Ca}^{2+}\right]_{i}$ was shown to prevent subsequent DNA fragmentation. Elevation of $\left[\mathrm{Ca}^{2+}\right]_{\mathrm{i}}$ may also, however, be a signal for clonal expansion and 
proliferation in mature thymocytes (35). Moreover, Rodriguez-Tarduchy et al. (36) have shown that A23187 inhibits apoptosis induced by IL-3 deprivation in an IL-3-dependent cell line, while also inducing cell cycle arrest.

The neutrophil's responses to elevation of $\left[\mathrm{Ca}^{2+}\right]_{i}$ thus appear strikingly different. Neutrophils undergo apoptosis constitutively with aging in vitro, but our studies show that an increased proportion of apoptotic cells within a population is not associated with elevated $\left[\mathrm{Ca}^{2+}\right]_{\mathrm{i}}$ (Fig. 5). Moreover, neutrophil lifespan is prolonged, via the inhibition of apoptosis, by inflammatory mediators such as FMLP, C5a, and IL-1 (14) at concentrations which are known to produce elevations of $\left[\mathrm{Ca}^{2+}\right]_{i}$ in the neutrophil similar to those measured here (15-17). Although the work of McConkey et al. (6) in lymphoid cells has shown rapid induction of apoptosis with equivalent doses of ionophores and equivalent elevations of $\left[\mathrm{Ca}^{2+}\right]_{i}$, the rises in $\left[\mathrm{Ca}^{2+}\right]_{\mathrm{i}}$ levels have been sustained. By contrast, elevations in the neutrophil were transient and $\left[\mathrm{Ca}^{2+}\right]_{\mathrm{i}}$ had returned to resting levels by $1 \mathrm{~h}$, despite the longer term effects upon the rate of apoptosis.

The "downstream" signaling pathways of this modulation of apoptosis are also of great importance and will be the subject of further studies. Calmodulin is a multifunctional calciumbinding protein involved in cell functions such as motility and contractility, but also in the calcium-dependent regulation of many enzymes (37). The ability of W-7 to promote apoptosis suggested that activation of a calcium:calmodulin dependent kinase may play a role in the inhibition of neutrophil apoptosis. Although W-7 may have effects upon other intracellular transduction systems, at the concentration of W-7 used in these studies $(60 \mu \mathrm{M})$ the predominant interaction of W-7 is likely to be with calmodulin rather than protein kinase-C $\left(K_{\mathrm{i}} 12 \mu \mathrm{M}\right.$ calmodulin; $K_{\mathrm{i}} 110 \mu \mathrm{M}$ PK-C) (38). Thus, a weak effect on PK-C cannot be excluded from these studies, but a more potent effect of W-7 upon calmodulin would be predicted. Again, the converse effect, promotion of apoptosis, has been observed with calmodulin inhibitor treatment of thymocytes (6), calmodulin perhaps being involved in regulating nuclear uptake of calcium (39). Early induction of the calmodulin gene has been reported in corticosteroid-induced apoptosis of WEHI 7.2 lymphocytes, in which calmodulin inhibitors were also shown to protect against apoptosis (40).

As shown in these studies, inhibition of apoptosis in the neutrophil is linked to functional upregulation and delayed macrophage removal. However, it is not unexpected that neutrophil mechanisms for control of apoptosis should differ from those of other cells of the immune system. The terminally differentiated neutrophil is short-lived (half-life in the circulation $\sim 6 \mathrm{~h}$ ) and apparently destined to die rapidly by apoptosis (41). Neutrophil activation, e.g., by inflammatory mediators, not only enhances neutrophil functional capacity but also delays the onset of apoptosis (14). Mechanisms may therefore exist for the inhibition of constitutive neutrophil apoptosis, linked to pathways of cellular activation, many of which are mediated, at least in part, by elevation of cytosolic calcium.

\section{Acknowledgments}

The authors would like to thank Dr. Alan Boobis for helpful discussions.

This work was supported by the Medical Research Council (MRC) of Great Britain. M. K. B. Whyte is in receipt of an MRC Training
Fellowship. J. S. Savill is a Wellcome Trust Senior Research Fellow in Clinical Science.

\section{References}

1. Cohen, J. J. 1991. Programmed cell death in the immune system. $A d v$. Immunol. 50:55-85.

2. Golstein, P., D. M. Ojcius, and J. Ding-E. Young. 1991. Cell death mechanisms and the immune system. Immunol. Rev. 121:29-65.

3. Wyllie, A. H., J. F. R. Kerr, and A. R. Currie. 1980. Cell death: the significance of apoptosis. Int. Rev. Cytol. 68:51-306.

4. Wyllie, A. H. 1980. Glucocorticoid-induced thymocyte apoptosis is associated with endogenous endonuclease activation. Nature (Lond.). 284:555-556.

5. Wyllie, A. H., R. G. Morris, A. L. Smith, and D. Dunlop. 1984. Chromatin cleavage in apoptosis: association with condensed chromatin morphology and dependence on macromolecular synthesis. J. Pathol. 142:67-77.

6. McConkey, D. J., P. Nicotera, P. Hartzell, G. Bellomo, A. H. Wyllie, and S. Orrenius. 1989. Glucocorticoids activate a suicide process in thymocytes through an elevation of cytosolic $\mathrm{Ca}^{2+}$ concentration. Arch. Biochem. Biophys. 269:365370.

7. McConkey, D. J., P. Hartzell, J. F. Amador-Perez, S. Orrenius, and M. Jondal. 1989. Calcium-dependent killing of immature thymocytes by stimulation via the CD3/T cell receptor complex. J. Immunol. 143:1801-1806.

8. Takahashi, S., H. T. Maecker, and R. Levy. 1989. DNA fragmentation and cell death mediated by $T$ cell antigen receptor /CD3 complex on a leukemia $T$ cell line. Eur. J. Immunol. 19:1911-1919.

9. Allbritton, N. L., C. R. Verret, R. C. Wolley, and H. N. Eisen. 1988. Calcium ion concentrations and DNA fragmentation in target cell destruction by murine cloned cytotoxic T lymphocytes. J. Exp. Med. 167:514-527.

10. Savill, J. S., A. H. Wyllie, J. E. Henson, M. J. Walport, P. M. Henson, and C. Haslett. 1989. Macrophage phagocytosis of aging neutrophils in inflammation. Programmed cell death in the neutrophil leads to its recognition by macrophages. J. Clin. Invest. 83:865-875.

11. Grigg, J. M., J. S. Savill, C. Saraff, C. Haslett, and M. Silverman. 1991. Neutrophil apoptosis and clearance by macrophages in the lungs of neonates with pulmonary inflammation. Lancet. 338:720-722.

12. Savill, J. S., I. Dransfield, N. Hogg, and C. Haslett. 1990. Vitronectin receptor-mediated phagocytosis of cells undergoing apoptosis. Nature (Lond.). 342:170-173.

13. Whyte, M. K. B., L. C. M. Meagher, and C. Haslett. 1990. Loss of functional responsiveness to surface stimuli in apoptotic neutrophils. J. Leukocyte Biol. (Suppl. 1):29.

14. Lee, A., S. K. Young, P. M. Henson, and C. Haslett. 1989. Modulation of neutrophil programmed cell death by inflammatory mediators. FASEB (Fed. Am. Soc. Exp. Biol.) J. 3:1344A.

15. Korchak, H. M., L. B. Vosshall, G. Zagon, P. Ljubich, A. M. Rich, and G. Weissmann. 1988. Activation of the neutrophil by calcium-mobilising ligands. I. A chemotactic peptide and the lectin concanavalin A stimulate superoxide anion generation but elicit different calcium movements and phosphoinositide remodeling. J. Biol. Chem. 263:11090-11097.

16. Lew, P. D., A. Monod, F. A. Waldvogel, and T. Pozzan. 1987. Role of cytosolic free calcium and phospholipase $C$ in leukotriene- $B_{4}$ stimulated secretion on human neutrophils. Eur. J. Biochem. 162:161-168.

17. Smith, R. J., D. E. Epps, J. M. Justen, L. M. Sam, M. A. Wynalda, F. A Fitzpatrick, and F.S. Yein. 1987. Human neutrophil activation with interleukin1: a role for intracellular calcium and arachidonic acid lipoxygenation. Biochem. Pharmacol. 36:3851-3858.

18. Haslett, C., L. A. Guthrie, M. A. Kopaniak, R. B. Johnston, and P. M. Henson. 1985. Modulation of multiple neutrophil functions by preparative methods or trace concentrations of bacterial lipopolysaccharide. Am. J. Pathol. 119:101-110.

19. Deber, C. M., J. Tom-Kun, E. Mack, and S. Grinstein. 1985. BromoA23187: a non-fluorescent calcium ionophore for use with fluorescent probes. Anal. Biochem. 146:349-352.

20. Hidaka, H., M. Asano, S. Iwadare, I. Matsumoto, T. Totsuka, and N. Aoki. 1978. A novel vascular relaxing agent (N[6-aminohexyl]-5-chloro-1naphthalene sulfonamide, $\mathrm{HCl}$ ) which affects vascular smooth muscle actomyosin. J. Pharmacol. Exp. Ther. 207:8-15.

21. Lew, V. L., R. Y. Tsien, and C. Miner. 1982. Physiological $\left[\mathrm{Ca}^{2+}\right]_{\mathrm{i}}$ level and pump-leak turnover in intact red cells measured using an incorporated $\mathrm{Ca}$ chelator. Nature (Lond.). 298:478-481.

22. Trauth, B. C., C. Klas, A. M. J. Peters, S. Matzku, P. Moller, W. Falk, K. M. Debatin, and P. H. Krammer. 1989. Monoclonal antibody-mediated tumor regression by induction of apoptosis. Science (Wash. DC). 245:301-305.

23. Karnad, A. B., K. L. Hartshorn, J. Wright, J. B. Myers, J. H. Schwartz, and A. I. Tauber. 1989. Priming of human neutrophils with $\mathrm{N}$-formyl-methionyl-leucyl-phenylalanine by a calcium-independent, pertussis toxin-insensitive pathway. Blood. 74:2519-2526. 
24. Grynkiewicz, G., M. Poenie, and R. Y. Tsien. 1985. A new generation of $\mathrm{Ca}^{2+}$ indicators with greatly improved fluorescence properties. J. Biol. Chem. 260:3440-3450.

25. Harsthorn, K. L., J. Wright, M. A. Collamer, M. R. White, and A. I. Tauber. 1990. Human neutrophil stimulation by influenza virus: relationship of cytoplasmic pH to cell activation. Am. J. Physiol. 258:C1070-C1076.

26. Tsien, R. Y. 1981. A non-disruptive technique for loading calcium buffers and indicators into cells. Nature (Lond.). 290:527-528.

27. Lew, P. D., A. Monod, F. A. Walsvogel, B. Dewald, M. Baggiolini, and T. Pozzan. 1986. Quantitative analysis of the cytosolic free calcium dependency of exocytosis from three subcellular compartments in intact human neutrophils. $J$. Cell Biol. 102:2197-2204.

28. Dewald, B., U. Bretz, and M. Baggiolini. 1982. Release of gelatinase from a novel secretory compartment of human neutrophils. J. Clin. Invest. 70:518525 .

29. Pozzan, T., D. P. Lew, C. B. Wollheim, and R. Y. Tsien. 1983. Is cytosolic ionized calcium regulating neutrophil activation? Science (Wash. DC) 221:1413-1415.

30. Verghese, M. W., C. D. Smith, and R. Snyderman. 1985. Potential role for a guanine nucleotide regulatory protein in chemoattractant receptor mediated polyphosphoinositide metabolism, $\mathrm{Ca}^{++}$mobilization and cellular responses by leukocytes. Biochem. Biophys. Res. Commun. 127:450-457.

31. Duvall, E., and A. H. Wyllie. 1986. Death and the cell. Immunol. Today. 7:115-119.

32. Cohen, J. J., and R. C. Duke. 1984. Glucocorticoid activation of a calcium-dependent endonuclease in thymocyte nuclei leads to cell death. $J$. Immunol. $132: 38-42$.
33. Smith, C. A., G. T. Williams, R. Kingston, E. J. Jenkinson, and J. J. T. Owen. 1989. Antibodies to CD3/T-cell receptor complex induce death by apoptosis in immature T cells in thymic cultures. Nature (Lond.). 337:181-184.

34. McConkey, D. J., P. Hartzell, S. K. Duddy, H. Hakansson, and S. Orrenius. 1988. 2,3,7,8-tetrachlorodibenzo-p-dioxin kills immature thymocytes by $\mathrm{Ca}^{2+}$-mediated endonuclease activation. Science (Wash. DC). 242:256-259.

35. Crabtree, G. R. 1989. Contingent genetic regulatory events in T lymphocyte activation. Science (Wash. DC). 243:355-361.

36. Rodriguez-Tarduchy, G., M. Collins, and A. Lopez-Rivas. 1990. Regulation of apoptosis in interleukin-3-dependent hemopoietic cells by interleukin-3 and calcium ionophores. EMBO (Eur. Mol. Biol. Organ.) J. 9:2997-3002.

37. Means, A. R. 1988. Molecular mechanisms of action of calmodulin. $R e$ cent Prog. Horm. Res. 44:223-259.

38. Tanaka, T., T. Ohmura, T. Yamakado, and H. Hidaka. 1982. Two types of calcium-dependent protein phosphorylations modulated by calmodulin antagonists. Mol. Pharmacol. 22:408-412.

39. Jones, D. P., D. J. McConkey, P. Nicotera, and S. Orrenius. 1989. Calcium-activated DNA fragmentation in rat liver nuclei. J. Biol. Chem. 264:63986403.

40. Dowd, D. R., P. N. MacDonald, B. S. Komm, M. R. Haussler, and R. Miesfeld. 1991. Evidence for early induction of calmodulin gene expression in lymphocytes undergoing glucocorticoid-mediated apoptosis. J. Biol. Chem. 266:18423-18426.

41. Fliedner, T. M., E. P. Cronkite, and J. S. Robertson. 1964. Granulocytopoiesis. I. Senescence and random loss of neutrophilic granulocytes in human beings. Blood. 24:402-414. 